\title{
WOVEN: THE MUSIC OF EGIDIJA MEDEKŠAITE்
}

\author{
Christopher Fox
}

\begin{abstract}
The Lithuanian composer Egidija Medekšaite (b. 1979) has developed a practice in which she uses the principles of textile weaving to make musical compositions. This article introduces a series of works created in the last three years in which she has refined these techniques; it also considers the nature of the relationship between the textile patterns that Medekšaite uses as the basis for these works and the resultant music. In particular the article focuses on an analytical account of four works: Âkâsha for string orchestra (2015), the string quartet Megh Malhar (2016), a setting of the Nunc dimittis (2018), and Sattva for electronics and accordion (2018).
\end{abstract}

I first encountered the music of Egidija Medekšaitè in a meeting room in a hotel in Bratislava in 2011. I was a member of the jury selecting works for the ISCM World New Music Days that would eventually be held in Vienna, Bratislava and Kosice in November 2013 and, as can happen after a day or two of score-reading, I was beginning to wonder whether we would ever find anything that departed from the lingua franca of international festival music. Every score was different, of course, but, as time passed, the familiarity of the Finale and Sibelius fonts, of the carefully calibrated musical rhetoric, of the recurrent narrative arc in so much of this music was dampening my spirits.

Then I started to look through the submissions from the Lithuanian ISCM section. I opened a score and there was a new voice in my inner ear, music in which subtly varied rhythmic figures animated extended harmonic fields. That voice belonged to Dhani (2009) a work for string quartet, percussion and accordion by Egidija Medekšaite. She had graduated in 2007 from the Lithuanian Academy of Music and Theatre, studying there with Rytis Mažulis, and by the time we eventually met in Kosice, a couple of days before the 2013 ISCM performance of Dhani, she had moved to Britain to begin a $\mathrm{PhD}$ in composition at Durham University. She was awarded the $\mathrm{PhD}$ in 2016 and still lives in Durham.

Perhaps the originality of a work from a Lithuanian composer should not have been so surprising. Like the other Baltic states, Lithuania has a rich musical culture: during the long years of political and social oppression by the Soviet Union music played a vital role in maintaining some sense of national identity and it was no accident that the first Head of State after Lithuania declared its independence from the Soviet Union in 1990 was the pianist and music theorist, Vytautas 
Landsbergis. Within 18 months Lithuania had achieved full statehood and so Egidija Medekšaite entered her teenage years in a country which was suddenly open to the whole world. It is dangerous to generalise, but perhaps this combination of newly won independence in a country that also had a highly distinctive musical culture was a particularly potent catalyst for exciting new work.

Soon after her arrival in Durham Medekšaitè's work came to the attention of the UK's national charity for new music, Sound and Music, who supported the creation of her Sandhi Prakash (2013) for string orchestra, premiered by Ruthless Jabiru, and Megh Malhar (2016) for string quartet, premiered by the Bozzini Quartet. So far so conventional; this could be a description of many emerging composer's career paths: conservatoire studies, a $\mathrm{PhD}$, festival performances and commissions. But a closer examination of Medekšaitè's curriculum vitae reveals an intriguing gap between 1997, the end of her secondary school years, and 2001, when she began her time at the Academy of Music. During these years she studied textile design and engineering at Kaunas Technical University, graduating with undergraduate and Masters degrees, and it is the influence of this fascination with textiles that I want to trace through some of the works she has created in the last five years.

Music is an ephemeral medium and so musicians and critics have habitually looked for metaphorical ways of discussing it, as a language, as dialogue, as drama, as a form of sonic architecture. Composers have compared what they do to designing computer programmes, editing film, even painting. Xenakis borrowed techniques from engineering and game theory, Feldman described the use of the sustaining pedal in Triadic Memories as a 'very precarious gesso smudge', a technique he said he had derived from a series of recent paintings by $\mathrm{Cy}$ Twombly. ${ }^{1}$ Each of these metaphors can tell us something about particular pieces of music but, because music is a phenomenon beyond language, their deployment often distracts us from the music's reality. In chapter 5 of Howards End E.M. Forster uses a Queen's Hall concert performance of Beethoven's Fifth Symphony to delineate the Schlegel sisters' characters - 'Helen, who can see heroes and shipwrecks in the music's flood... Margaret, who can only see the music ${ }^{2}$ - but Helen's fantasies are no more fanciful than Lendvai's Golden Section measurements in his analyses of the music of Bartok: neither explains the sensation of hearing this music.

In her $\mathrm{PhD}$ thesis Medekšaite establishes an extensive provenance for her deployment of weave patterns. For example, she cites the research of Professor Manolete Mora ${ }^{3}$ into the interconnectedness of weaving and musicmaking in the Philippines:

the fundamental principles of the weaving designs of the T"boli people of the Southern Philippines are analogous with the concepts underlying the instrumental composition Utom. Mora argues that there are three compositional elements that are basic to both weaving and instrumental music, the main design, ornamentation, and 'ground' ... Mora demonstrates that these connections can be found in K'lutang seko performance, which is performed by two women each using a pair of wooden mallets. One performer plays the Utom (main design), and the other performs the Tang (ground) in a closely coordinated,

\footnotetext{
1 Morton Feldman, 'Toronto Lecture, 17 April 1982', Morton Feldman Says: Selected Interviews and Lectures 1964-1987, ed. Chris Villars (London: Hyphen Press, 2006), p. 148.

2 E.M. Forster, Howards End (London: Edward Arnold, 1910), p. 21.

3 Manolete Mora, 'Tune and Textile: Interrelatedness in the Music and Weaving Arts of the T'boli', UP Diliman Journals, 9, no. 2 (2012), p. 3.
} 
interlocking manner. The 'counterchange', as Mora describes it, between Utom and Tang occurs as a result of unstable figure-ground relations, as the attention of the eye and ear in the visual and aural domains, respectively, shift back and forth between figure and ground and the two elements are 'woven' together.

In the domain of orchestral music Medekšaitè acknowledges that 'the most significant and enduring musical influence' on her $\mathrm{PhD}$ portfolio was Morton Feldman's Coptic Light (1985): 'Feldman's aesthetic response to early Coptic textiles, which he had seen in the Louvre, inspired my own research in this area. Coptic Light exemplifies his interest in the distinctive treatment of repetition as metaphor for pattern in the visual arts'. She goes on, however, to suggest a distinction between Feldman's work and her own:

The repetitions in Feldman's piece are rarely exact, using inflections in rhythm, register, and timbre to create a subtle transformation of timbre and harmony over the duration of the piece as a whole. Having said that, Feldman's transformation process relies on a more intuitive/creative approach when transforming textile pattern into sound, whilst my intention is to explore the latent possibilities engendered in more direct mappings, in order to find particular characteristics that determine the language of the process. ${ }^{5}$

For Medekšaite, then, there is a significant difference between Feldman's 'intuitive/creative approach', in which the repetitions within Turkish and Persian rugs, or Coptic textiles, provide a model for 'inflections in rhythm, register, and timbre', and her own methodology, which involves 'direct mappings' of textile patterns into sound, in an attempt to explore 'latent' qualities within the patterns. In her thesis she discusses this relationship between textile and sonic design:

The strict structure behind my music does not necessarily have to restrain its expressive power, but I hope that, on the contrary, it can add to it. As a textile designer and engineer, I consider textile weaves as texture, ambience, sonority, an atmosphere, or motion, which I transfer into a particular composition. The structure of a primary weave or the overall textile serves as a background, or guide in order to shape the composition, through predefined musical parameters, such as dynamics, harmony, timbre, and rhythm which add a specific colour to the weave and generates a particular atmosphere. The chosen mapping method itself is a creative decision, one that combines fundamental characteristics of both the visual and the audible, creating a new identity and interaction between each. ${ }^{6}$

It is this distinction - between textile design as a constructive metaphor for musical processes, and music in which weave patterns become, at least in part, the subject - that makes Egidija Medekšaitè's work so unusual.

Less significant perhaps, but rather more immediately striking, is Medekšaitè's regular use of Indian titles for her works, usually transliterated from Sanskrit. Often, although not always, these refer to the ragas of north Indian classical music: Sandhi Prakash, for example, the string orchestra work for which I was the workshop mentor in 2013, takes its title from the collection of ragas suitable for the period at dawn and dusk in which night turns into day and back again. In an interview with the website Radikaliais she summarises her music as 'the compilation of Indian music and textile mapping', citing as a particularly important source Ravi Shankar’s 1986 recording Incredible

\footnotetext{
${ }^{4}$ Egidija Medekšaite, 'Mapping Textile Patterns into Sonic Experience' (PhD thesis, Durham University, 2016), pp. 17-18.

${ }^{5}$ Egidija Medekšaitè, 'Mapping Textile Patterns', p. 21.

${ }^{6}$ Egidija Medekšaite, 'Mapping Textile Patterns', p. 46.
} 
Ravi Shankar - Raga Charukauns. ${ }^{7}$ I will return to the question of the Indian-ness of Medekšaitė's music later.

\begin{abstract}
$\hat{A} k \hat{a} s h a$
Like all surface pattern design disciplines, textile design is an interface between aesthetic and industrial processes. A designer may imagine images, whether illustrative or abstract, but if they are to be realised they must be translated into a grid of threads running at right-angles to one another, warp and weft. Since the industrialisation of the mideighteenth century, weaving, perhaps more than any other branch of textile manufacture, has become a highly complex process in which abstract or illustrative designs are converted into a set of instructions for the machines on which the woven fabric is created. These instructions determine not only the sequencing and tension of the different coloured threads that form the fabric but also its eventual strength and pliability. A pattern may appear complicated but, if the fabric is to be robust, the interweaving of threads that produces that pattern must be as simple as possible.

Egidija Medekšaite's background in this complex, industrial approach to weaving translates into musical processes that, as she said above, determine 'dynamics, harmony, timbre, and rhythm', or perhaps more exactly, changes in loudness, pitch, playing techniques and duration. Whereas in Morton Feldman's music the influence of rug design is essentially heard as a series of reiterated figures set against a background of more or less instrumental resonance, Medekšaitè's weaving patterns control the deployment of various different types of musical activity. At its most obvious this can be heard in the opening of her 2016 work for amplified string orchestra Âkâsha. Twenty-one musicians (six violin I, five violin II, four violas, four celli, and two double basses) are playing divisi, bowing the scrolls of their instruments. Each makes a crescendo from $p p p$ to $m f$ - effectively from silence to audibility - but the crescendi are staggered through each division of the orchestra.

In her programme note for the work, ${ }^{8}$ Medekšaite explains that she found the concept of Âkâsha in a book by Swami Vivekananda, Raja-Yoga And Patanjali's Yoga Aphorisms (2012):
\end{abstract}

The whole universe was composed of two materials, one of which is called Âkâsha. It is the omnipresent, all-penetrating existence. Everything that has form, everything that is the result of combination, is evolved out if this Âkâsha. It is the Âkâsha that becomes the air, that becomes the liquids, that becomes the solids; it is the Âkâsha that becomes the sun, the earth, the moon, the stars the comets; it is the Âkâsha that becomes the human body, the animal body, the plants, every form that we see, everything that can be sensed, everything that exits; it can not be perceived, it is so subtle that it is beyond all ordinary perception; it can only be seen when it has become gross, has taken form. At the beginning of creation there is only this Âkâsha. At the end of the cycle the solids, the liquids, and the gases all melt into the Âkâsha again, and the next creation similarly proceeds out if this Âkâsha.

Swami Vivekananda is describing a process of becoming, of forming, and in Medekšaitè's Âkâsha the noise-rich sounds produced by the string players bowing the body of their instruments very slowly give way to sounds with more pitch content. The weaving of entries

\footnotetext{
7 'Composer EGIDIJA MEDEKŠAITĖ: "My music is the compilation of Indian music and textile mapping"', at www.radikaliai.lt/garsas-sound/3639-composer-egidija-medeksaitemy-music-is-the-compilation-of-indian-music-and-textile-mapping, accessed 27 November 2018.

${ }^{8}$ Egidija Medekšaitè, Âkâsha, title pages.
} 
Example 1:

Egidija Medekšaitè, Âkâsha (2015), pitch collection from bars 174-192 continues throughout the work, as does the divisi writing, and all the musicians play continuously: in almost all Medekšaitè's works she resists any temptation to break the fabric of sound. Over 12 minutes the music rises in intensity from the barely audible sounds of the opening to double-stopped glissandi and tremoli (often marked 'noisy, blurry'), to radiant double-stopped harmonies across the orchestra (Example 1 shows the total pitch collection at this point) and, finally, a crescendo on the same harmonies, now played tremolandi with the added instruction that the players should 'gradually change timbre to sound distortion/noise'.

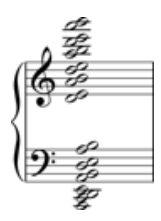

It is significant that the passage from Swami Vivekananda, quoted above, describes a process of creation that goes from Âkâsha into 'form' - solids, liquids, gases - at the end of which these forms melt back into Âkâsha, whereas Medekšaitè's Âkâsha traces only the forming process. As listeners we are, presumably, being invited to imagine how these musical solids, liquids and gases might 'all melt into the Âkâsha again, and the next creation similarly proceed'. The result is a work whose inexorable, irreversible trajectory has great expressive power, the weaving together of the developing instrumental soundscape creating music that consistently engages the ear until it reaches its powerful climax. The same trajectory also characterises the string quartet, Megh Malhar, which Medekšaitè wrote immediately before Âkâsha; because of its smaller scale I shall examine this work in greater detail.

\section{Megh Malhar}

The word 'Megh' in Sanskrit means 'cloud' and Megh Malhar is an Indian classical raga used both to suggest the coming of thunder and rain and to summon rain clouds in times of drought. Medekšaite says of the piece:

My intention was to use this raga in such a way that it might resemble the illusion of sparkling dew, in which each droplet reflects the microscopic world of the rain. Each string player performs various trills in extremely slow tempo in order to maintain this fragile sense of sound. For me, this music is about the weaving of raindrops or dew into one fragile and transparent pattern. ${ }^{9}$

Medekšaite wrote Megh Malhar for the Bozzini Quartet, developing the work during a week-long workshop with them in Montreal in May 2015 as part of the quartet's annual 'Composers' Kitchen' project, a scheme which that year was part of Sound and Music's 'Embedded' programme. Four composers had been selected, two from Britain (Medekšaite and Georgia Rodgers) and two from Canada (Kyle Brenders and James O'Callaghan). There were also two composermentors, Christopher Butterfield and me, so I was able to observe

${ }^{9}$ Egidija Medekšaite, Megh Malhar (2016), introduction to the score. 
Example 2:

Egidija Medekšaitė, Megh Malhar (2016), bars 1-17
Medekšaitè's creative process at first hand. The Bozzinis gave the world premiere on 5 February in 2016, in the Sound Festival in Scotland, repeating the work in the Netherlands at the 2016 Gaudeamus Festival and in Vancouver at the 2017 ISCM World New Music Days, and it continues to be a regular feature of their repertoire.

What quickly became clear in the Montreal workshops was the precision of Medekšaitè's aural imagination. We gathered on the first day in an eighth-floor rehearsal room in Concordia University and the first music that the Bozzinis chose to work on was the score that Medekšaite had prepared. They began to play but within a minute she interrupted them, evidently unhappy that what she was hearing was not as she had imagined it. Over the next four days the process was repeated - new notations prepared, played, rejected - until eventually the score took a satisfactory form and the quartet could begin to rehearse rather than just try out material.

One might argue that this is unremarkable: after all, the composer's role in notated music consists of no more than finding a symbolic representation for what they expect to hear. What was telling in the Montreal workshops, however, was the extent to which Medekšaitè's conception for her music was entirely integrated. In many works it is possible to alter a detail or two, a phrase, even a whole section, without having to remake the whole work, but
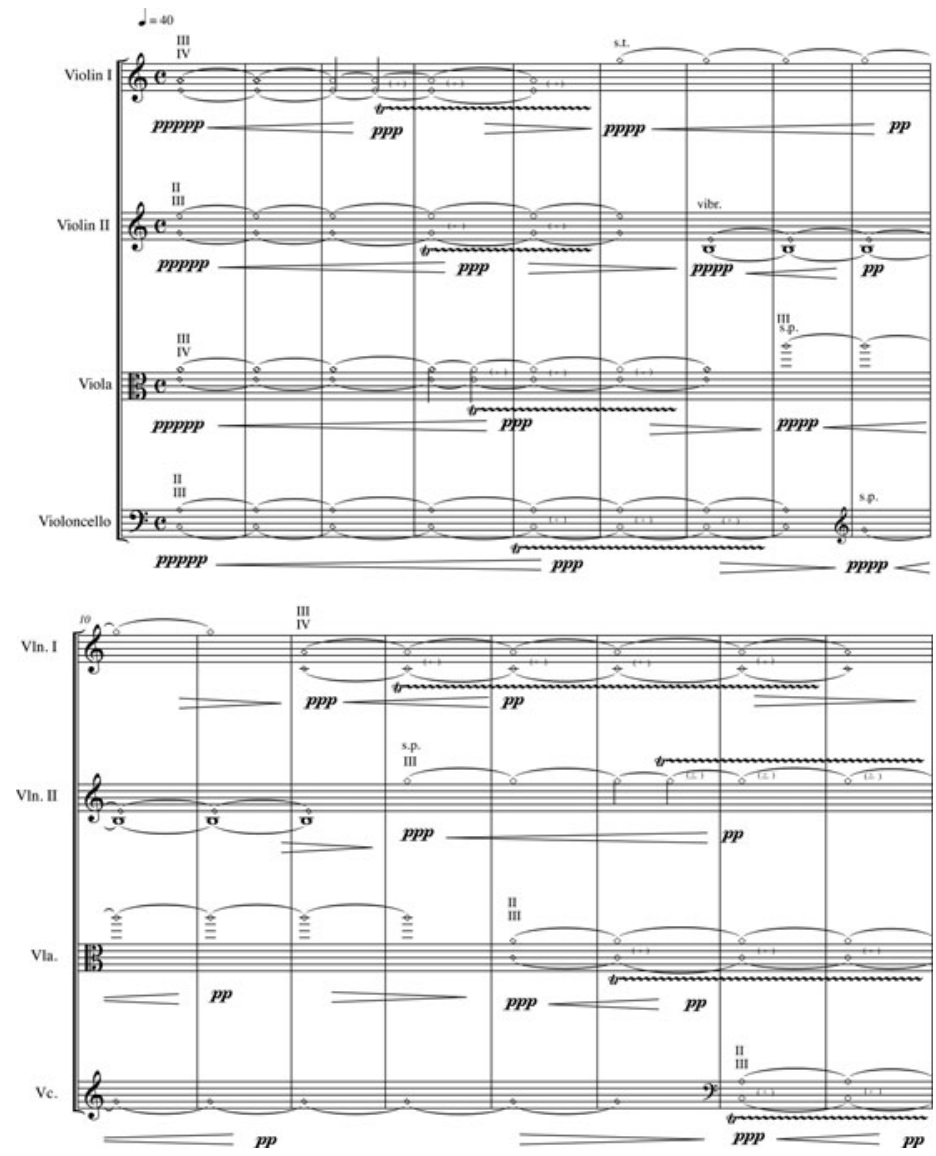
Example 3a:

Egidija Medekšaitè, Megh Malhar (2016), opening pitch collection

Example 3b:

Egidija Medekšaitè, Megh Malhar (2016), closing pitch collection because everything within Megh Malhar - all the different ways of sounding the instruments, all the connections between the instruments - is connected, and connected from the beginning of the music to its conclusion, any sort of piecemeal revision was impossible.

The eventual result was a work with a single sonic trajectory, lasting about eight and a half minutes in the Bozzinis' performance. The four musicians play continuously, their bows never leaving the strings, each player's part made up of sustained sounds, mostly double-stops, often with trills on one or the other string to animate the sound. As can be seen in Example 2, Megh Malhar begins with a collection of extremely quiet harmonics that yield the pentatonic collection shown in Example 3a. The strings are stopped at various nodes (the fourth, fifth, sixth, octave and tenth) so that the resultant harmonics have different sonic qualities. Starting at the edge of silence the music becomes more audible and from bars 3 to 5 a series of trills passes round the quartet. This initial weave pattern is relatively simple, going from left to right in standard quartet formation, but whereas the onset of each trill is at a three-second interval, the end of the trills is at a six-second interval. The next weave - trills again, from bars 13 to 16 - is more complicated, zigzagging from violin I to viola to violin II to cello at twelve-, three-, and three-second intervals.

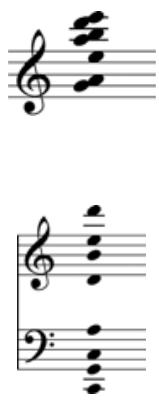

Dynamic levels rise very slowly, with the first $p$ after two minutes, the first $m p$ after three minutes 40 seconds, the first $m f$ after four minutes. More playing techniques are also introduced - transitions from non-vibrato to vibrato, transitions from sul ponticello to sul tasto and, as with the initial trills, these serve to animate the sound rather than having any specific expressive purpose. Finally, over a minute, all four players come together in a single tremolo crescendo from ppp to ff, played sul ponticello and eventually marked 'dense, noisy scratching' 24 seconds before the end of the piece. As can be heard in the Bozzinis' 2017 ISCM performance, ${ }^{10}$ any clear pitch content is gradually overwhelmed by the noise generated by the increasing intensity of the tremolandi bowing, but when the crescendo begins it is possible to hear the pitch collection shown in Example 3b. Like the opening collection, shown in Example 3a, it is derived from a white-note mode, but with a fundamental two octaves and a fifth below that opening collection; one of the reasons the end of the 
piece feels so emphatically conclusive is because it spells out a perfect cadence.

Given the work's title one might reasonably ask, how Indian is it? A listener who is unaware of the work's title or its meaning will probably hear nothing Indian in it at all and, even with that knowledge, it is impossible, for this listener at least, to hear any moment in the music at which the raga emerges. Nevertheless the music does seem to offer a 'megh malhar' metaphor and one which goes beyond 'the weaving of raindrops' promised in the composer's programme note. When I first heard the finished work in Montreal in 2015 I was struck by its musical logic, by its seamless and inevitable progression from a colouring of silence to a tumultuous noise, but after several hearings I suddenly realised that the last minute can also be heard as a wonderful depiction of a late-afternoon tropical downpour. The quartet devotedly prays for rain and, in the end, it comes.

\section{Nunc dimittis}

Roman Catholicism has been an important element within Lithuanian national identity for centuries, establishing its difference from the Orthodox Christianity of its Russian neighbour and decisively placing Lithuania within the western European division of Christendom. Medekšaitè's Catholic faith is also an important element within her own life, although until recently this faith had not been explicitly expressed in her music. In 2017, however, she was commissioned to make a setting of the Magnificat for the choir of Canterbury Cathedral and, as is traditional for composers of sacred choral music, she quickly followed this with a setting of the Nunc dimittis. Both are remarkable works, occupying a unique musical territory that seems to acknowledge both the choral traditions of the Baltic states and the polyphonic tradition of sixteenth-century English sacred music, and the Nunc dimittis in particular offers a highly compressed version of Medekšaitè's compositional method.

Medekšaitė takes the Biblical text from the Gospel of St Luke (2:29-32):

Nunc dimittis servum tuum, Domine, secundum verbum tuum in pace:

Quia viderunt oculi mei salutare tuum

Quod parasti ante faciem omnium populorum:

Lumen ad revelationem gentium, et gloriam plebis tuae Israel.

(Lord, now lettest thou thy servant depart in peace, according to thy word: For mine eyes have seen thy salvation, Which thou hast prepared before the face of all people; A light to lighten the Gentiles, and the glory of thy people Israel.)

adding the usual doxology:

Gloria Patri et Filio et Spiritui sancto,

Sicut erat in principio, et nunc et semper et in saecula saeculorum. Amen. (Glory to the Father, and to the Son, and to the Holy Ghost; as it was in the beginning, is now, and ever shall be. Amen.)

She sets the words syllabically to create a work which lasts about five minutes. There are eight vocal parts, SSAATTBB, all of whom, in Medekšaitè's characteristic manner, sing continuously throughout the work, and the syllables of the text cascade through the voices, as shown in Example 4. This staggering of entries is a familiar device both in the polyphonic vocal writing of the Renaissance and in many more recent works, Ligeti's Lux aeterna being perhaps the finest example within the modernist repertoire. But the mode of imitation 
in Medekšaitë's Nunc dimittis is much more complex than in previous choral polyphony.

Example 4:

Egidija Medekšaitè, Nunc dimittis (2018), page 1

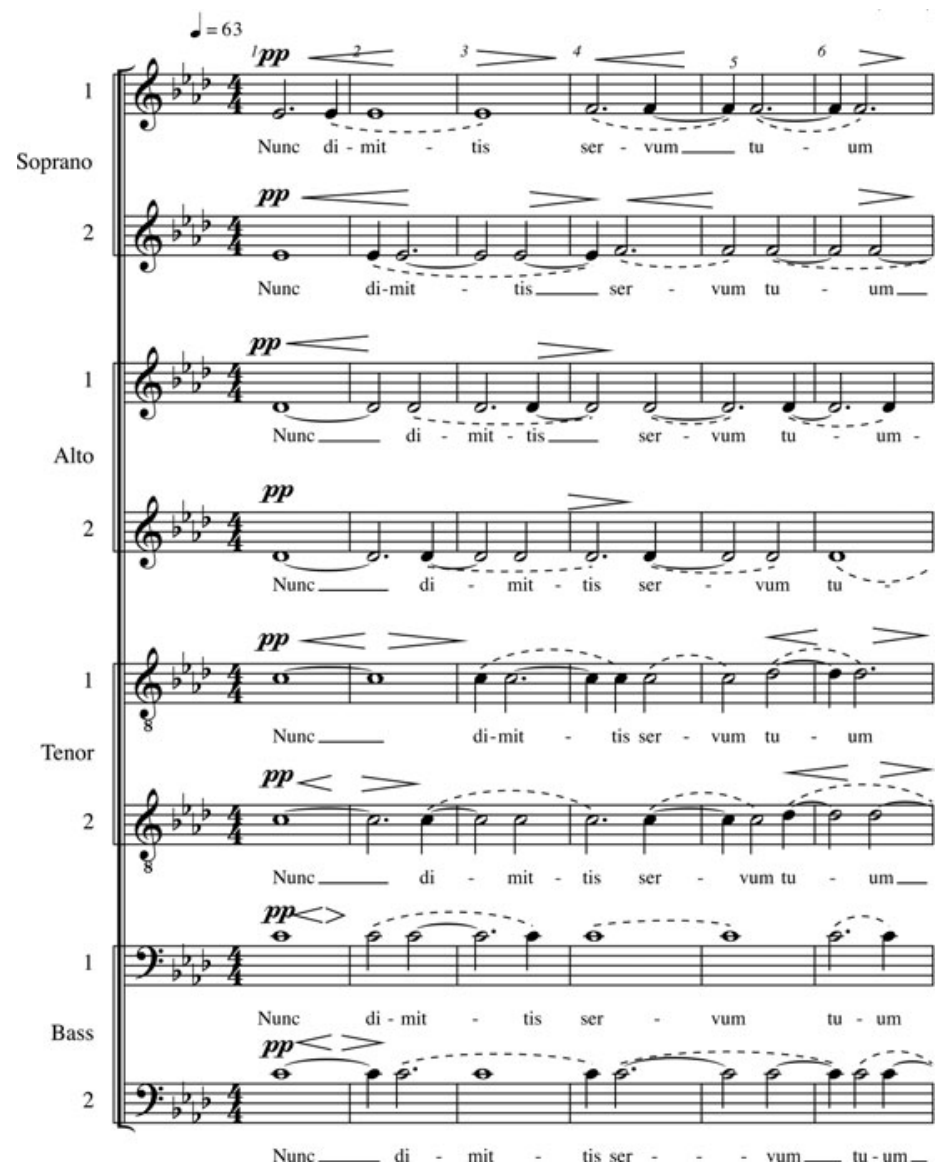

Instead of the canonic polyphony of Ligeti's Lux aeterna or the elaborate succession of imitative entries in the polyphonic writing of a composer like William Byrd, the polyphony of Medekšaite's Nunc dimittis is based, as anyone who has read this far would probably now expect, on a weaving pattern. For example, the succession of the four syllables of 'nunc dimittis' in the opening bars shown in Example 4 can be diagrammatically reduced to the design shown in Example 5. Rather than a simple voice-by-voice set of entries Medekšaite presents a complex weaving together of all eight voices: I am no weaver, but I suspect that, realised on a loom, this would produce a fabric both sturdy and flexible.

As in most of Medekšaite's other recent works this music has a very clear overall trajectory, beginning with the voices in a close-position modal cluster and ending on an $\mathrm{F}$ minor triad that reaches from the basses's bottom $\mathrm{F}$ to the soprano's Ab (Example 6 shows the principal stages of this opening out of the pitch-space; numbers above the stave indicate the bar number in which each new collection begins). Closer examination of the score, however, reveals a fascinating hierarchical 
Example 5:

Egidija Medekšaitè, Nunc dimittis, diagrammatic representation of syllabic setting in bars $1-10$

Example 6:

Egidija Medekšaitè, Nunc dimittis, progressive opening out of pitch-space

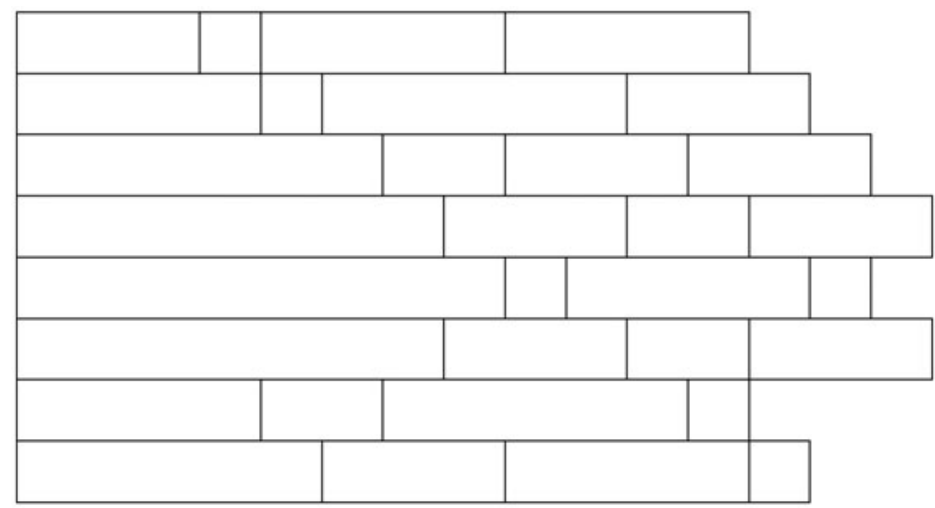

network between the voices. Example 7 shows the succession of pitches within each part and demonstrates how each of the upper voices has progressively fewer different pitches than the one above it, from 48 in soprano 1 , to 42 in soprano 2, 24 in alto 1 and 17 in alto 2 . Tenors 1 and 2 have 18 and 17 pitches respectively, and then the progressive reduction continues, with 10 and 9 pitches in the basses.

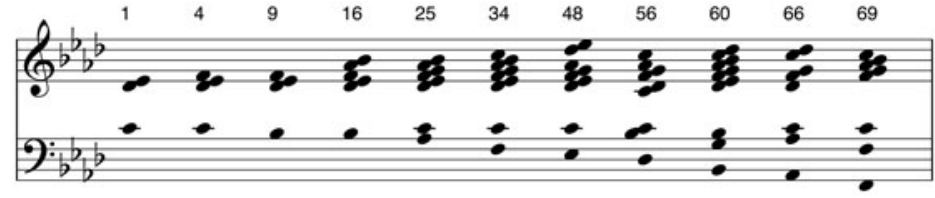

Example 7 also makes clearer Medekšaitè's very individual approach to polyphony. The sopranos have extended melodic contours in which stepwise movement is followed by larger intervals from which the melody generally then descends, before the stepwise movement resumes, and there are close similarities between the two parts. In the alto 1 part these melodic contours are flattened out, depressed further in alto 2 and tenor 1 and reduced to a continuous stepwise movement between middle $\mathrm{C}$ and $\mathrm{D}$ flat in tenor 2. Bass 1 has what one might think of as a radical reduction of the soprano 1 part - a descent, an ascent and another descent - and bass 2 simply descends.

\section{Sattva}

In 2011 my introduction to Egidija Medekšaitè's music had been with Dhani, an ensemble work in which the accordion acts as a sort of sonic foundation. In Sattva (2018), commissioned by the Lithuanian Composers' Union for the electronic music festival, Jauna Muzika, and premiered in Vilnius on 24 April 2018 by accordionist Raimondas Sviackevičius, she returned to the instrument, but this time as an amplified soloist in combination with a 20-track electronic soundscape. The title, so the composer tells us in the score, is a Sanskrit word with many meanings: she cites 'spirit, essence, 
Example 7:

Egidija Medekšaitè, Nunc dimittis, pitch sequences in each vocal part

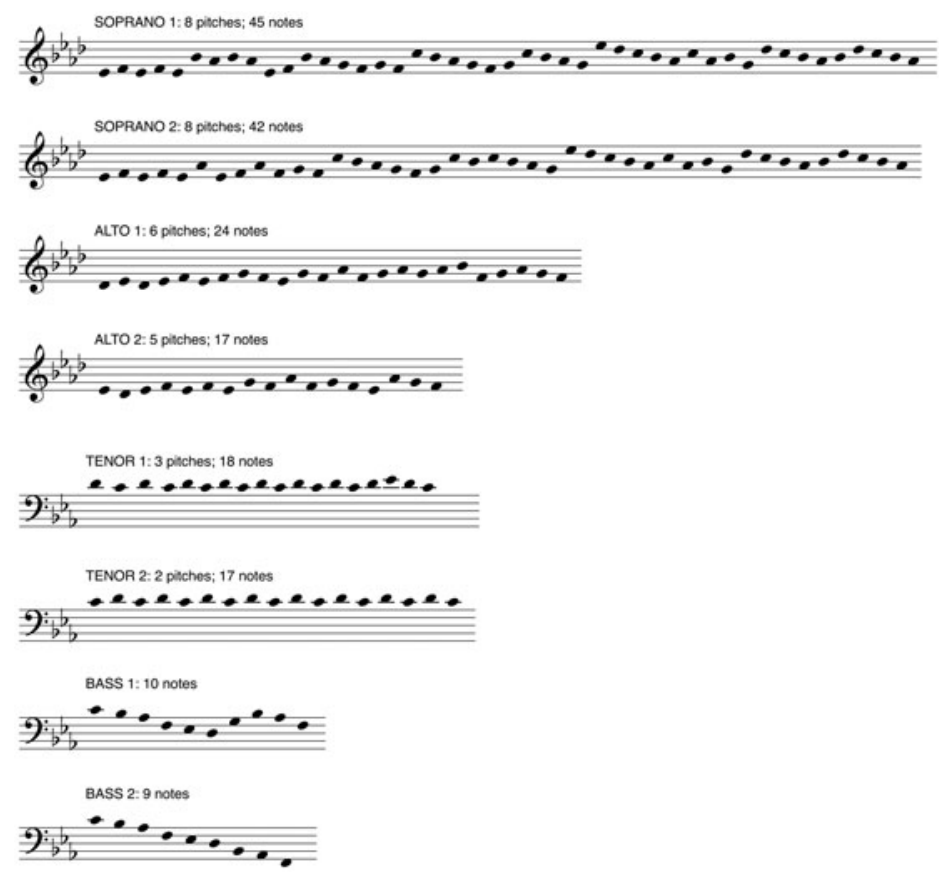

demon, monster, vital breath, matter, creature, wisdom'. ${ }^{11}$ Perhaps behind all these overlapping meanings is the sense of something inchoate, of a sort of source material, and Medekšaitè's Sattva is very much a work in which musical matter is allowed to emerge.

The electronic part forms the basis of the music, with the live accordionist's part doubling notes heard in the loudspeakers, each new collection of notes marked by a crescendo, so that the accordion effectively becomes an acoustic amplifier or magnifying glass. The electronic part consists of sustained, synthesized accordion tones and is structured around a durational scheme in which initial units of six bars are gradually augmented, an extra bar at a time, until eventually they are 24 bars long. Each unit consists of a single tone, beginning with the $\mathrm{D}$ below the bass clef, then the $\mathrm{C}$ a tone lower, and then the same notes in the two octaves above. It is more than two minutes before a new note, a B, arrives in the electronics, although change has been anticipated in the live accordionist's part by an octave $\mathrm{C} \# 30$ seconds earlier.

So far so straightforward, but Medekšaite enriches this sonic mix by introducing slight deviations in pitch in the electronic part. At the beginning we hear Ds from both manuals of the live accordion, but the first six-bar-long D in track 1 of the electronics is tuned 3.125 cents flat, the second D 6.25 cents flat, the third 9.375 cents flat, and so on, until the final ' $\mathrm{D}$ ', heard ten minutes later at the end of the piece, is a tone lower, a C in fact. It's a simple device, repeated in many of the other tracks - sometimes with the pitch deviations going up rather than down - that nevertheless creates an astonishingly rich aural result, the tones in the electronics beating against one another and also against the amplified accordion. It might also be

${ }^{11}$ Egidija Medekšaitė, Sattva (2018), introduction to the score. 
Example 8:

Egidija Medekšaitè, Sattva,

bellow-shake chords, $9^{\prime} 06^{\prime \prime}$ and $9^{\prime} 32^{\prime \prime}$ heard as a composing-out of one of the inherent features of the accordion itself, the tiny differences in pitch between the two banks of reeds that produce the instrument's distinctive timbre.

After the painstakingly slow, but microtonally varied, accretion of pitches at the start of the work, Sattva's harmonic development gradually picks up speed. At each augmentation of the tone-length a new tone on a new track is added and after the severe pitch restrictions of the opening two minutes the harmony becomes more conventionally complex, building up a series of shifting chromatic clusters in different registral dispositions. At last, nine minutes into the piece, a 24-barlong $\mathrm{F} \approx$ appears in track 20 to complete the process and, as if to celebrate this completion, the accordionist has a triumphant bellows-shake on the first chord shown in Example 8, then another on the second chord in Example 8, before the music melts away into silence, the long descent from D to C finally accomplished.

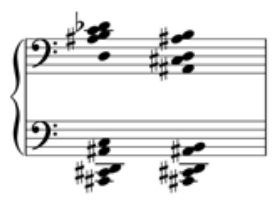

It's a marvellously dramatic conclusion, effective because after such a patient accumulation the end comes so quickly. As a realisation of the 'spirit' of sattva it's also entirely satisfactory: at the point at which the 'vital breath' has achieved utterance the music stops, as it must. It seems to me that Sattva is also a benchmark in Egidija Medekšaitè's continuing development as a composer. The timbral storm that ends Megh Malhar is spectacular, but its arrival arrests the work's harmonic development; in Sattva, however, the musical processes flow inexorably into and through its climax.

On the other hand, as the last piece to be discussed in an article that began by focusing on the role of weaving patterns as a means of organising music, Sattva is, to the ear at least, Medekšaitè's least obviously woven work. In music that is exclusively made up of long tones, all of them bound together by the timbre of the accordion, that is, of course, inevitable, but an examination of the score reveals, once again, a meticulous overlapping of sonic strands. It is this integration of material - pitches, duration, timbre - within a musical structure that makes listening to Medekšaitès work such a rewarding experience. These are painstakingly well-designed lengths of tonal fabric, made to last. 